\title{
Combined multi-modal assessment of glaucomatous damage with electroretinography and optical coherence tomography/ angiography
}

\section{Authors and affiliations}

Khaldoon O. Al-Nosairy¹, Gokulraj Prabhakaran¹, Konstantinos Pappelis², Hagen Thieme ${ }^{1}$, Michael B. Hoffmann ${ }^{1,3}$

1Department of Ophthalmology, Otto-von-Guericke University, Magdeburg, Germany 2Department of Ophthalmology, University of Groningen, University Medical Center, Groningen, The Netherlands

${ }^{3}$ Center for Behavioral Brain Sciences, Magdeburg, Germany

word count: 3670

Abstract: 250

Tables: 4

Figures: 4

\section{Correspondent details:}

Michael B. Hoffmann

Department of Ophthalmology, Otto-von-Guericke University, Leipziger Str. 44, 39120 Magdeburg, Germany

Phone: $\quad+493916713585$

Fax: $\quad+493916713570$

Email: michael.hoffmann@med.ovgu.de 
medRxiv preprint doi: https://doi.org/10.1101/2020.07.05.20145714; this version posted July 7, 2020. The copyright holder for this preprint (which was not certified by peer review) is the author/funder, who has granted medRxiv a license to display the preprint in perpetuity.

\begin{abstract}
Purpose: To compare the diagnostic performance and to evaluate the interrelationship of electroretinographical and structural and vascular measures in glaucoma.
\end{abstract}

Methods: For 14 eyes of 14 healthy controls and 15 eyes of 12 patients with glaucoma ranging from preperimetric to advanced stages OCT, OCT-A and electrophysiological measures [multifocal photopic negative response ratio (mfPhNR) and steady state pattern electroretinogram (SSPERG)] were applied to assess changes in retinal structure, microvasculature, and function, respectively. The diagnostic performance was assessed via area-under-curve (AUC) measures obtained from ROC analyses. The interrelation of the different measures was assessed with correlation analyses.

Results: mfPhNR and ssPERG amplitudes, parafoveal (pfVD) and peripapillary vessel density ( $p V D$ ), macular ganglion cell inner plexiform layer thickness (mGCIPL) and peripapillary retinal nerve fibre layer thickness ( $P R N F L)$ were significantly reduced in glaucoma. The AUC for mfPhNR was highest among diagnostic modalities (AUC: 0.88, 95\%-Cl: 0.75-1.0, $\mathrm{P}<0.001$ ), albeit not statistically different from that for macular (mGCIPL: 0.76, 0.58-0.94, $\mathrm{P}<0.05$; pfVD: 0.81, .65-.97, $\mathrm{P}<0.01$ ) or peripapillary imaging (pRNFL: 0.85, 0.70-1.0, $\mathrm{P}<0.01$; pVD: 0.82, 0.68-0.97, $\mathrm{P}<0.01$ ). Combined functional/vascular measures yielded the highest AUC (mfPhNR-pfVD: 0.94, 0.85-1.0, $P<0.001$ ). The functional/structural measure correlation (mfPhNR-mGCIPL correlation coefficient $\left(r_{s}\right)$ : 0.58, $P=0.001$; mfPhNR-pRNFL $r_{s}: 0.66, P<0.0001$ ) was stronger than the functional-vascular correlation (mfPhNR-pfVD $r_{s}: 0.29, P=0.13$; mfPhNRpVD rs: 0.54, $\mathrm{P}=0.003)$.

Conclusions: The combination of ERG measures and OCT-A improved diagnostic performance in glaucoma. Combing ERG, structural and OCT-A parameters provides an enhanced understanding of the pathophysiology of glaucoma.

Keywords: glaucoma; multifocal photopic negative response; pattern electroretinogram; OCT-Angiography; vessel density; retinal ganglion cells 
medRxiv preprint doi: https://doi.org/10.1101/2020.07.05.20145714; this version posted July 7 , 2020. The copyright holder for this preprint (which was not certified by peer review) is the author/funder, who has granted medRxiv a license to display the preprint in perpetuity.

\section{INTRODUCTION}

Glaucoma is a progressive optic neuropathy characterized by the loss of retinal ganglion cells (RGCs) and eventually visual field (VF) defects (Kwon et al. 2009). Damage to RGCs is attributed to an increase in intraocular pressure (IOP) (mechanical theory) or primary vascular dysfunction (vascular theory) (Flammer 1994, Flammer et al. 2002, Halpern \& Grosskreutz 2002, Mansouri 2016). Elevated IOP is an important risk factor for the development of primary open angle glaucoma (POAG) (Bahrami 2006), the most prevalent glaucoma type (Tham et al. 2014), while vascular dysfunction might be particularly critical for normal tension glaucoma (NTG) (Mansouri 2016). However, vascular changes were also proposed for POAG (Bonomi et al. 2000, Mroczkowska et al. 2013, Salowe et al. 2015). Surrogate measures in clinical practice to estimate glaucomatous damage are macular ganglion cell inner plexiform layer (mGCIPL) and peripapillary retinal nerve fiber layer ( $p R N F L)$ thickness measures obtain via optical coherence tomography (OCT) (Kim et al. 2017, Mwanza et al. 2012, Oddone et al. 2016); however, conventional structural OCT assessment does not enable the quantification of vascular changes in glaucoma (Gao et al. 2016). Using the OCT platform for 3-D angiography allows for optical coherence tomography angiography (OCT-A), a recent innovation in imaging technology. In fact, OCT-A has opened the possibility of non-invasive evaluations of retina and optic nerve vasculature in glaucoma (Akil et al. 2018, Jia et al. 2012, Kim et al. 2017, Penteado et al. 2018, Yarmohammadi et al. 2016) to further our understanding of the underlying pathophysiology and to improve glaucoma detection. Vessel density parameters of macular and peripapillary areas measured with OCT-A have a similar diagnostic performance as retinal thickness measures obtained with conventional OCT (reviewed in (Van Melkebeke et al. 2018)). In fact, vessel density measures of OCT-A were 
medRxiv preprint doi: https://doi.org/10.1101/2020.07.05.20145714; this version posted July 7 , 2020. The copyright holder for this preprint (which was not certified by peer review) is the author/funder, who has granted medRxiv a license to display the preprint in perpetuity. It is made available under a CC-BY-NC-ND 4.0 International license .

strongly correlated with both structural OCT measures and functional indices (standard automated perimetry; SAP) (Van Melkebeke et al. 2018).

Although it is well known that OCT-A correlates with visual field sensitivities (Ghahari et al. 2019, Liu et al. 2015, Yarmohammadi et al. 2016), there is limited information of OCT-A measures correlation with direct measures of retinal ganglion cell function. This gap can be filled by combining OCT-A parameters with electroretinographic (ERG) measures. Two ERG-based approaches provide sensitive information about the pathophysiology of glaucoma damage (Wilsey \& Fortune 2016), i.e. pattern ERG (PERG) and the photopic negative responses (PhNR). They are therefore of paramount importance for the objective assessment of retinal function in glaucoma. The PERG is an established method with promising outcomes for glaucoma diagnosis (Bode, Jehle \& Bach 2011, Preiser et al. 2013). The PhNR is a more recent development to quantify glaucomatous damage (Kirkiewicz, Lubiński \& Penkala 2016, Preiser et al. 2013, Viswanathan et al. 2001), which has been applied in a conventional manner and in combination with the multifocal stimulation technique (Sutter 2001), i.e., mfPhNR (Kaneko et al. 2015, Kato et al. 2015, Van Alstine \& Viswanathan 2017).

Taken together, a combined approach of structural, vascular and functional assessment of glaucomatous retinal damage employing OCT, OCT-A and $\mathrm{PERG} / \mathrm{mfPhNR}$ is of great promise to uncover the interrelationship between the different components of ocular damage in glaucoma and to shed light on the underlying patho-mechanisms. A recent study (Honda et al. 2019) demonstrated that in NTG the PhNR amplitude was correlated with macular vessel density and concluded that vascular changes might precede structural measures in early NTG. We aimed to assess such relationships for POAG. For this purpose, we correlated two types of ERG methods (PERG and mfPhNR) vs structural (OCT based) and vascular (OCT-A based) 
medRxiv preprint doi: https://doi.org/10.1101/2020.07.05.20145714; this version posted July 7 , 2020. The copyright holder for this preprint (which was not certified by peer review) is the author/funder, who has granted medRxiv a license to display the preprint in perpetuity.

changes of macular and peripapillary areas. This multimodal approach opens a window to assess how these structural, vascular and functional measures of retinal damage are linked to peripapillary and macular damage sites, and to each other. The aim of the present study was twofold: (i) to compare the diagnostic performance of individual measures and of combined measures of ERG and structural or vascular parameters; (ii) to elucidate the interrelation of ERG measures of retinal ganglion cell function with structural and vascular parameters and their association with macular and peripapillary sites. We found ERG measures (PERG/mfPhNR) to be more strongly correlated with structural (especially peripapillary) measures and less with vascular measures. Combined assessments of multifocal photopic negative responses (mfPhNR) and parafoveal vessel density measures (pfVD) improved the diagnostic power of glaucoma detection.

\section{METHODS}

\section{Participants}

12 glaucoma patients and 14 age-matched healthy controls were included in this observational study after giving written consent to participate in the study. ERG data of the study participants were part of another study (Al-Nosairy, Thieme \& Hoffmann 2020). The procedures followed the tenets of the declaration of Helsinki and the protocol was approved of by the ethical committee of the Otto-von-Guericke University of Magdeburg, Germany. The study was performed in the ophthalmological department of the Otto-von-Guericke University Hospital, Magdeburg. All participants underwent best corrected visual acuity testing for far (BCVA) and near, visual field testing, OCT/-A measurements, and an ophthalmic examination. 
medRxiv preprint doi: https://doi.org/10.1101/2020.07.05.20145714; this version posted July 7 , 2020. The copyright holder for this preprint (which was not certified by peer review) is the author/funder, who has granted medRxiv a license to display the preprint in perpetuity.

Healthy controls. 14 eyes of 14 subjects (mean age \pm , standard error of mean (SE): 50.2 years, 3.8) with BCVA $\geq 1$ were included in the study.

Glaucoma-group. 15 eyes of 12 patients (mean age \pm , SE: 55.3 years, 3.7; no age difference to control group $(P=0.35$; $t$-Test $)$ ), with open angle glaucoma were enrolled in this study. The group comprised 7 preperimetric and 8 perimetric glaucomatous eyes. The 7 preperimetric glaucoma patients with an open anterior chamber, had a glaucomatous optic disc damage defined via a vertical cup-to-disc ratio $\geq 0.7$, a retinal fiber layer defect or a local notching of the rim. The 8 perimetric glaucoma eyes had glaucomatous visual field defects manifested as a cluster of 3 or more non-edge points all depressed on the pattern deviation plot $<5 \%$ and one of which depressed $<1 \%$ or abnormal corrected pattern standard deviation $<5 \%$ on Humphrey Swedish interactive threshold algorithm 24-2 (SITA fast) (Anderson \& Patella 1999).

Exclusion criteria were any systemic diseases, ocular diseases or surgeries that might affect electrophysiological recordings except cataract surgery and, in the glaucoma group, glaucoma surgery or BCVA $<0.8$ (Bach \& Mathieu 2004) and refractive error exceeding $\pm 5 \mathrm{D}$ or astigmatism $>2 \mathrm{D}$. Insufficient quality of OCT images was also an exclusion criteria. An overview of participants' characteristics is given in Table 1.

\section{Visual field testing}

Visual field sensitivities were assessed using the Swedish Interactive Threshold Algorithm 24-2 protocol (SITA-Fast) of the Humphrey Field Analyzer 3 (Carl Zeiss Meditec AG, Jena, Germany).

\section{OCT Angiography acquisition and image analysis}

OCT images were acquired using the Spectralis HRA+OCT equipped with the Angiography, the Glaucoma and the Flex Module. Both eyes were scanned for macula 
medRxiv preprint doi: https://doi.org/10.1101/2020.07.05.20145714; this version posted July 7 , 2020. The copyright holder for this preprint (which was not certified by peer review) is the author/funder, who has granted medRxiv a license to display the preprint in perpetuity. It is made available under a CC-BY-NC-ND 4.0 International license .

and disc scans. OCT angiographical images and structural measures were then exported for further analysis.

Structural measures. Averaged macular retinal nerve fiber layer thickness and ganglion cell inner plexiform layer (GCIPL) thickness were assessed inside the $3 \mathrm{~mm}$ (pfRNFL and pfGCIPL, respectively) and $6 \mathrm{~mm}$ (mRNFL and mGCIPL, respectively) rings of ETDRS scan and exported for further analysis (Figure $1 \mathrm{I} \& \mathrm{~J}$ ). The averaged peripapillary retinal nerve fiber layer thickness (pRNFL) was calculated within $3.4 \mathrm{~mm}$ circle around the disc. Global indices of macula and peripapillary structure measures, i.e. mGCIPL and pRNFL thickness, respectively, were compared to other parameters. Angiographical measures. Spectralis OCT-A enables distinctive mapping of three vascular layers of the retina, superficial vascular plexus (SVP), intermediate capillary plexus (ICP) and deep capillary plexus (DCP) (Hosari et al. 2020). We focused our analysis on the SVP layer that nourishes macular GCLIPL (mGCIPL) and peripapillary superficial vascular complex (SVC) layer, which includes the peripapillary radial capillaries supplying the pRNFL (Campbell et al. 2017, Iwasaki \& Inomata 1986). OCTA images were exported in the form of transverse analysis from the Heidelberg Engineering interface. High speed scans $\left(20^{\circ}\right)$ were used and $768 \times 768$ pixel images were utilized. SVP (Figure 1A), ICP and DCP of parafovea were evaluated. Each layer was analyzed separately with a MATLAB- script (Pappelis \& Jansonius 2019) described below. Only the peripapillary superficial vascular complex (SVC) of the peripapillary area perfusion was evaluated with the current script (Figure 1D).

With the MATLAB-based script (Pappelis \& Jansonius 2019) used for analysis, images were imported and one region of interest ( $\mathrm{ROI}$ ) (see below) was defined after determining the center of macula and disc for macular and disc perfusion quantification by the same investigator, respectively. SVP, ICP and DCP were calculated 
medRxiv preprint doi: https://doi.org/10.1101/2020.07.05.20145714; this version posted July 7 , 2020. The copyright holder for this preprint (which was not certified by peer review) is the author/funder, who has granted medRxiv a license to display the preprint in perpetuity. It is made available under a CC-BY-NC-ND 4.0 International license .

automatically, once the ROI center was determined manually by the investigator. Binary images of macula and optic disc were generated and each vessel pixel and tissue pixel were represented as white and black, respectively. A local Otsu threshold (Otsu 1979) to binarize an image was applied to flow- and no-flow signals. The ROI of the macula was a circle with $3 \mathrm{~mm}$ diameter centered on the macula (Figure $1 \mathrm{C}$ ) and the ROI around the optic disc was a ring shaped with inner and outer radii of 1.03 and $1.84 \mathrm{~mm}$ (Figure $1 \mathrm{~F})$. The big blood vessels of the optic nerve head $(\mathrm{ONH})$ images were masked out with a Frangi vesselness filter using eignenvectors of the Hessian filter response of image (Frangi et al. 1998) (Figure $1 \mathrm{G} \& \mathrm{H}$ ). To assess the reproducibility of the applied script, repeated analysis of the same OCT-A images were compared between the OCT-A data of the study population. Pairwise comparisons did not identify significant differences between the 2 iterations of image processing $(P>$ 0.05). Intraclass correlations between both data sets of SVP, ICP and DCP showed excellent agreement of all measures (95\% CI of ICC: $0.99-1.0, \mathrm{P}<0.001)$.

The following parameters were evaluated: (1) Fractal dimension (FD). FD is an index of the branching complexity of the capillary network and ranges from 1 to 2 , with a higher FD indicating a greater vessel branching pattern. FD was calculated based on a box-counting technique where the image is subdivided into square boxes of equal sizes and the number of boxes covering a vessel segment is counted. This was repeated for different box sizes. The logarithmized box number was plotted vs logarithmized box size, where the FD equals the slope of the regression line (Masters 2004, Reif et al. 2012). (2) Vessel density (VD) [\%]. VD is the percentage of the area occupied by capillaries. The peripapillary parameters of FD and VD were denoted as pFD and pVD to differentiate them from parafovea pfFD and pfVD parameters. Only the parafoveal and peripapilary SVP were compared to other functional and structural 
medRxiv preprint doi: https://doi.org/10.1101/2020.07.05.20145714; this version posted July 7 , 2020. The copyright holder for this preprint (which was not certified by peer review) is the author/funder, who has granted medRxiv a license to display the preprint in perpetuity. It is made available under a CC-BY-NC-ND 4.0 International license .

parameters. In the literature, the most frequently reported measure of microvasculature in glaucoma is VD. Consequently, we focused on VD, also in Discussion, specifically as we obtained similar findings for FD and VD.

\section{Visual stimuli, procedure and recordings of mfPhNR and ssPERG}

Multifocal photopic negative response (mfPhNR). For mfPhNR recording, VERIS Science 6.4.9d13 (EDI: Electro-Diagnostic Imaging, Redwood City, CA, USA) was used for stimulus delivery and electrophysiological recordings. The stimulus comprised 5 visual field locations covering $48^{\circ}$ of visual field with central and four quadrants $\left(0-5^{\circ}\right.$ and $5^{\circ}-48^{\circ}$, respectively). A binary m-sequence of 0 (no flash) and 1 states (flash) was used for stimulation with a length of $2^{9}-1$ steps and 9 frames (frequency of stimulation: $4.2 \mathrm{~Hz}$ ). Each step lasted $13.3 \mathrm{~ms}$ resulting in total recording time of $61 \mathrm{~s}$. Two mfPhNR blocks were recorded and averaged. A monochrome CRT monitor (MDG403, Philips; P45 phosphor) was used for the stimulus presentation at $75 \mathrm{~Hz}$ frame rate and the measurements were inspected in real-time on a separate monitor. In accordance with previous studies, mfPhNR were normalized to b-wave amplitude, both measured from the baseline, defined as the initial $10 \mathrm{~ms}$ of the epoch. The resulting mfPhNR ratio was compared between groups. We reported only $\mathrm{mfPhNR}$ ratio of the summed response of 5 visual field locations (Figure $1 \mathrm{~K}$ ), as this was previously identified to be the most accurate measure in mfPhNR-based glaucoma diagnostics (Al-Nosairy, Thieme \& Hoffmann 2020).

Steady state Pattern ERG (ssPERG). The EP2000 evoked potential system was used for stimulation, recording and analysis of steady-state PERGs (Bach n.d.) following the PERG-standard of the international society for clinical electrophysiology of vision (ISCEV) (Bach et al. 2013). The stimuli were presented at a frame rate of 75 Hz on a monochrome monitor (MDG403, Philips; P45 phosphor) subtending a visual 
medRxiv preprint doi: https://doi.org/10.1101/2020.07.05.20145714; this version posted July 7 , 2020. The copyright holder for this preprint (which was not certified by peer review) is the author/funder, who has granted medRxiv a license to display the preprint in perpetuity.

angle of $62^{\circ} \times 49^{\circ}$. A $15 \mathrm{~Hz}$ checkerboard pattern stimulus with two check sizes $\left(0.8^{\circ}\right.$ and $15^{\circ}$ ) was used for stimulation (figure $\left.1 \mathrm{~L}\right)$. Following established procedures (Bach \& Hoffmann 2008), the PERG ratio is calculated as an amplitude ratio of checksizes 0.8 to $15^{\circ}$.

In separate sessions, mfPhNR and ssPERG were recorded binocularly using active DTL (Dawson, trick Litzkow 1979, Thompson, Drasdo, 1987) electrodes (DTL Electrode ERG, Unimed electrode Supplies, Ltd, UK).

The pupils were dilated only for the mfPhNR recordings. Further details on the procedure and recording, analysis of mfPhNR and ssPERG are given in (Al-Nosairy et al. 2020, Al-Nosairy, Thieme \& Hoffmann 2020, Preiser et al. 2013). Only the ssPERG $0.8^{\circ}$ amplitude (ssPERG amplitude) and averaged $\mathrm{mfPhNR} / \mathrm{b}$-wave ratio (mfPhNR ratio) were compared to the acquired vascular and structural parameters.

\section{Statistics}

mfPhNR ratio (mfPhNR) and ssPERG amplitude were calculated using IGOR (IGOR Pro, WaveMetrics, Portland) and exported to SPSS 26 (Statistical Package for the Social Sciences, IBM), and R statistical system (R Core Team (2013) n.d.) for further analysis. The normality of the data was checked by applying the Shapiro-Walk test. Ttests or Mann-Whitney tests were conducted for cross-modal comparisons between groups and effect sizes of these tests were also reported as a d value and $U$ [\%] which represented the probability percentage of non-overlap between two distributions (Fritz, Morris \& Richler 2012). Correlations between measures were calculated using Spearman's coefficient $\left(r_{\mathrm{s}}\right)$ and the 95\% confidence interval of the coefficient was calculated using a bootstrapping method. The variances explained by the correlations $\left(r_{s}^{2}\right)$ were also calculated and reported. Receiver operating characteristics analyses 
medRxiv preprint doi: https://doi.org/10.1101/2020.07.05.20145714; this version posted July 7 , 2020. The copyright holder for this preprint (which was not certified by peer review) is the author/funder, who has granted medRxiv a license to display the preprint in perpetuity. It is made available under a CC-BY-NC-ND 4.0 International license .

were conducted using SPSS to calculate area under curve (AUC) to discriminate between controls and glaucoma. Pairwise comparisons of all measures' AUCs were assessed to check for any significant difference between them (Hanley \& McNeil 1983). $P$ values were corrected for multiple testing with adjusted $\alpha$-levels $\left(P_{\alpha}\right)$ using the Bonferroni-Holm correction (Holm 1979) where applicable. To verify the reproducibility of the applied MATLAB analysis script, intraclass correlation of analyses between two sets of repeated analysis of the same OCT-A images and 95\% confidence intervals $(95 \% \mathrm{Cl})$ were calculated based on absolute-agreement and 2way mixed-effects model (Koo \& Li 2016). MATLAB R2019b (MathWorks, Natick, Massachusetts) was used for OCT-A image processing.

\section{RESULTS}

\section{Functional and structural parameters vs electrophysiological and vascular measures}

Electrophysiology. The electrophysiological measures of retinal ganglion cell function showed differential responses between the groups. The mfPhNR ratio was significantly different in glaucoma and the difference between the groups represented $75 \%$ of the non-overlapping distribution $(d=1.7, P \leq 0.025=0.0002)$. Similarly, the difference between healthy and glaucoma ssPERG amplitudes was statistically significant $\left(d=1.1, P_{\leq 0.05}=0.006\right)$, for effect sizes see Figure $2 A$ and $B$.

Perimetry. On average, functional measures of glaucoma in terms of VF-MD [dB] and pattern standard deviation (PSD) $[\mathrm{dB}]$ were statistically different between the study groups $\left(\mathrm{d}=2.3, \mathrm{P}_{\leq 0.025}<0.0001\right.$ and $\mathrm{d}=1.3, \mathrm{P}_{\leq 0.05}=0.003$, respectively; see Table 1).

OCT. pRNFL were significantly lower in glaucoma patients with a substantial effect size of $1.8\left(P_{\leq 0.025}=0.001\right)$ (Figure $\left.2 \mathrm{C}-\mathrm{D}\right)$. The mRNFL was not statistically different 
medRxiv preprint doi: https://doi.org/10.1101/2020.07.05.20145714; this version posted July 7 , 2020. The copyright holder for this preprint (which was not certified by peer review) is the author/funder, who has granted medRxiv a license to display the preprint in perpetuity.

between the groups $(P>0.05)$. In contrast, pfGCIPL and mGCIPL thickness were significantly lower in glaucoma $\left(d=1.1, P_{\leq 0.05}=0.023\right.$ and $d=1.4, P_{\leq 0.025}=0.009$, respectively; see Table 1).

OCT-angiography. In terms of vascular estimates for the parafoveal ROI, we were particularly interested in the inner retinal layer supplied by SVP (for effect sizes see Figure $3 \mathrm{E}-\mathrm{H})$. Parafoveal FD (pfFD) $\left(\mathrm{d}=1.3, \mathrm{P}_{\leq 0.025}=0.003\right)$ and parafoveal VD (pfVD) $\left(d=1.1, P_{\leq 0.05}=0.008\right)$ were significantly reduced in glaucoma. For the peripapillary ROI perfused by SVC, pFD showed a significant decrease $\left(d=1.7, P_{\leq 0.025}\right.$ $=0.0016)$ as well as pVD $\left(d=1.5, P_{\leq 0.05}=0.0019\right)$ in glaucoma patients. It is notable that both ICP and DCP showed significant pfFD and pfVD reductions in glaucoma (P $<0.01$ ) compared to controls (Table 3).

\section{Discriminatory performance of ERG, structural parameters and vascular} parameters

In terms of the discriminatory performance between controls and glaucoma, we applied ROC-analyses to compare ERG measures of RGC-function (mfPhNR ratio, ssPERG amplitude), established structural (i.e., mGCLIPL thickness, pRNFL thickness) vascular measures of parafoveal and optic nerve (pfFD and pfVD as well as $p F D$ and $p V D)$. With respect to the ERG measures of RGC-function, there was a, non-significant trend for higher AUC (AUC, 95\% Cl, P value) for the mfPhNR ratio $\left(0.88,0.75-1.0, P_{\leq 0.025}<0.001\right)$ than for the ssPERG amplitude $\left(0.81,0.64-0.99, P_{\leq 0.05}\right.$ $=0.004)$. Therefore, our further analyses were focused on mfPhNR ratio. With respect to the structural assessment, there was a non-significant trend for higher AUC for pRNFL $\left(0.85,0.70-1.0, P_{\leq 0.025}=0.001\right)$ than for mGCIPL $\left(0.76,0.58-0.94, P_{\leq 0.05}=\right.$ 0.018). AUCs for vascular parameters were calculated for pfFD $(0.82,0.66-0.98$, $\left.\mathrm{P}_{\leq 0.025}=0.0037\right)$ and for pfVD $\left(0.81,0.65-0.97, \mathrm{P}_{\leq 0.05}=0.005\right)$ compared to $\mathrm{pFD}(0.86$, 
medRxiv preprint doi: https://doi.org/10.1101/2020.07.05.20145714; this version posted July 7 , 2020. The copyright holder for this preprint (which was not certified by peer review) is the author/funder, who has granted medRxiv a license to display the preprint in perpetuity.

0.72-0.99, $\left.\mathrm{P}_{<0.025}=0.001\right)$ and $\mathrm{pVD}\left(0.82,0.68-0.97, \mathrm{P}_{\leq 0.05}=0.003\right.$; see Figure 3$)$.

Finally, by conducting pairwise comparisons of ERG measures of RGC-function, structural and vascular AUCs, we found no significant differences $(P>0.05)$ between these measures indicating a similar and complementary performance in terms of differentiating glaucoma from controls. By testing the combined approach to identify the highest discriminatory performance, mfPhNR-pfVD and mfPhNR-pVD had the highest AUC for the differentiation between glaucoma and controls (AUC: 0.94, 0.91, respectively; $\mathrm{P}<0.001)$.

\section{Association between ERG, structural parameters and vascular parameters}

To elucidate associations between functional and other metrics, we investigated the correlation between vascular estimates of inner layers macula and peripapillary zones vs other structural and ERG measures of RGC-function. Both pfFD and pfVD were strongly correlated with pf/mGCLIPL thickness $(P \leq 0.001$; Table 4). Similarly vascular estimates of peripapillary perfusion showed a strong significant association with pRNFL thickness $(P \leq 0.0001)$. Our ERG measure of RGC-function, the mfPhNR ratio, was strongly correlated with all structural macula and peripapillary disc parameters as well as visual field-MD ( $P \leq$ p.001). ssPERG amplitude was also significantly correlated to pRNFL, mGCIPL and VF-MD ( $P=0.003,0.027$ and 0.003 , respectively), but not to pfGCIPL $(P=0.09)$. Out of the vascular measures, the mfPhNR ratio as well as ssPERG amplitude were significantly correlated only with $p F D$ and $p V D(P<0.01$; see table 4 and figure 4$)$.

To further elucidate glaucomatous damage mechanisms, we investigated the association between ERG-based functional indices with anatomical indices at damage sites. ERG-based functional measures at the peripapillary site (i.e. mfPhNR-pRNFL 
medRxiv preprint doi: https://doi.org/10.1101/2020.07.05.20145714; this version posted July 7 , 2020. The copyright holder for this preprint (which was not certified by peer review) is the author/funder, who has granted medRxiv a license to display the preprint in perpetuity.

$r_{s}: 0.66, P=0.0001$ and mfPhNR-pVD $\left.r_{s}: 0.54, P=0.003\right)$ exceeded those at the macular site (i.e. mfPhNR-mGCIPL $r_{s}: 0.58, P=0.001$ and mfPhNR-pfVD rs: $0.29, P$ $=0.13)$.

\section{DISCUSSION}

Applying a set of complementary retinal imaging modalities we demonstrated a significant effect of glaucoma on vascular (OCT-A; parafoveal vessel density "pfVD" and fractal dimension "pfFD" and peripapillary pVD and pFD), electrophysiological (mfPhNR and ssPERG amplitude) and structural measures (OCT; mGCIPL/pRNFL). These measures had equivalently high discriminatory performance, which further improved for the combination of the methods. The ERG measures of retinal ganglion cell function were more strongly associated with structural than with vascular measures.

Our findings of significant changes in the ocular microvasculature (VD) in glaucoma support previous studies, that demonstrated glaucomatous changes in the VD of the macular/parafoveal superficial layers (Akil et al. 2018, Chung et al. 2017, Penteado et al. 2018, Rao et al. 2016, Yarmohammadi et al. 2018) and the peripapillary area (Chung et al. 2017, Liu et al. 2015, Rao et al. 2016, Scripsema et al. 2016, Yarmohammadi et al. 2018). Further, they are in agreement with investigations that demonstrated glaucoma associated changes in mfPhNR and PERG (Al-Nosairy, Thieme \& Hoffmann 2020, Bode, Jehle \& Bach 2011, Preiser et al. 2013) and mGCIPL and pRNFL (Kim et al. 2017, Mwanza et al. 2012, Oddone et al. 2016). We considerably extended these studies by demonstrating an association between ERGbased functional and anatomical indices as well as an enhanced diagnostic efficacy of combined ERG-based functional indices with vascular indices. 
medRxiv preprint doi: https://doi.org/10.1101/2020.07.05.20145714; this version posted July 7 , 2020. The copyright holder for this preprint (which was not certified by peer review) is the author/funder, who has granted medRxiv a license to display the preprint in perpetuity.

\section{Cross-modal comparison of glaucoma detection}

In order to assess the benefit of any of the applied modalities for glaucoma detection, we conducted ROC analyses and compared their outcome measures, i.e. AUC. The only previous cross-modal study addressing this for early glaucoma detection (Kurysheva et al. 2018), demonstrated ssPERG to have a higher performance (AUC $=0.92)$ than whole image $\mathrm{VD}$ in macula and disc $(\mathrm{AUC}=0.80$ and 0.74 , respectively $)$ and ganglion cell complex thickness $(\mathrm{AUC}=0.74)$. In the current study, the highest discrimination performance was observed for the mfPhNR (not tested in (Kurysheva et al. 2018); $A \cup C=0.88$ ), albeit not being significantly different from other measures' AUCs. Subsequently, we investigated the effect of combining ERG measures of RGCfunction with structural or vascular measures. In fact, the combination of mfPhNR with pfVD and pVD AUCs yielded the highest AUC (0.94 and 0.91, respectively; $P<0.001)$, indicating an improvement of diagnostic performance. In addition to its relevance for glaucoma diagnosis, the improved performance for the combined assessment with these two modalities might also suggest that the ERG measures of RGC-function and OCT-A measures reflect distinctive glaucomatous damage mechanisms within the retina. It should be noted, however, that, as an alternative, the enhancement might also be due to decreasing the effect of noise by pooling data from different modalities.

\section{Association of ERG, structural, and vascular measures in glaucoma}

Given the relation of vascular changes with glaucoma, it is currently still unresolved, whether these are secondary or primary events associated with RGCs damage (Mansouri 2016). Previous OCT-A studies are inconclusive as they found structural changes either to precede (Akagi et al. 2016, Kim et al. 2017, Lee et al. 2017) or succeed (Honda et al. 2019, Shoji et al. 2017) vascular changes in glaucoma. We investigated the interrelation of these measures with the sensitive measures of RGC- 
medRxiv preprint doi: https://doi.org/10.1101/2020.07.05.20145714; this version posted July 7 , 2020. The copyright holder for this preprint (which was not certified by peer review) is the author/funder, who has granted medRxiv a license to display the preprint in perpetuity. It is made available under a CC-BY-NC-ND 4.0 International license .

function, mfPhNR and ssPERG amplitude (Al-Nosairy, Thieme \& Hoffmann 2020, Bode, Jehle \& Bach 2011, Preiser et al. 2013), in order to elucidate glaucomatous damage mechanisms. For this purpose, we compared the association of retinal ganglion cell dysfunction with specific changes (i) in fundus anatomy, i.e., microvasculature (OCT-A) and retinal structure (OCT), and (ii) at damage sites, i.e. macular and peripapillary sites: (i) Fundus anatomy. We reported a stronger correlation of RGC-function ( $\mathrm{mfPhNR} / \mathrm{ssPERG}$ ) with retinal structure $\left(r_{s} \leq 0.66\right)$ than with the microvasculature $\left(r_{s} \leq 0.56\right)$. In contrast, for NTG the reverse pattern was recently reported (Honda et al. 2019), i.e. a stronger association of PhNR with measures of macular/parafoveal microvasculature $(r \leq 0.42)$. Taken together, these findings support the current view that NTG is more strongly associated with vascular damage mechanisms than POAG. (ii) Damage sites. The measures of RGC-function were more strongly associated with peripapillary than with macular structural and vascular measures (mfPhNR with pRNFL and pVD rs: 0.66 and 0.54 , respectively; mfPhNR with mGCIPL and pfVD $r_{s}: 0.58$ and 0.29 , respectively). This suggests that damage mechanisms exert their action preferentially at the peripapillary zone. It must be noted, however, that in the present study glaucomatous damage ranged from preperimetric to advanced glaucoma, such that e.g. early stage changes of the macula (Hood et al. 2013, Kim et al. 2017, Kim, Jeoung \& Park 2017) might not have been relevant.

In conclusion, combining ERG and OCT-A measures may improve the assessment and eventually the management of glaucoma. Follow-up studies comparing the effects of glaucoma on retinal electrophysiology, microvasculature, and structure with larger sample sizes and employing longitudinal designs are of promise to further explore the pathophysiology of glaucoma. 
medRxiv preprint doi: https://doi.org/10.1101/2020.07.05.20145714; this version posted July 7, 2020. The copyright holder for this preprint (which was not certified by peer review) is the author/funder, who has granted medRxiv a license to display the preprint in perpetuity. It is made available under a CC-BY-NC-ND 4.0 International license .

\section{Acknowledgements}

This work was supported by European Union's Horizon 2020 research and innovation programme under the Marie Sklodowska-Curie grant agreement (No. 675033) and by funding of the German research foundation (DFG; HO2002/20-1) to $\mathrm{MBH}$.

Conflict of interest statement - None 
medRxiv preprint doi: https://doi.org/10.1101/2020.07.05.20145714; this version posted July 7 , 2020. The copyright holder for this preprint (which was not certified by peer review) is the author/funder, who has granted medRxiv a license to display the preprint in perpetuity.

\section{REFERENCES}

Akagi T, Iida Y, Nakanishi H, et al. (2016): Microvascular Density in Glaucomatous Eyes With Hemifield Visual Field Defects: An Optical Coherence Tomography Angiography Study. Am J Ophthalmol 168: 237-249.

Akil H, Chopra V, Al-Sheikh M, Falavarjani KG, Huang AS, Sadda SR \& Francis BA (2018): Swept-source OCT angiography imaging of the macular capillary network in glaucoma. Br J Ophthalmol 102: 515-519.

Al-Nosairy KO, Bosch JJONV den, Pennisi V, Thieme H, Mansouri K, Choritz L \& Hoffmann MB (2020): Interaction of intraocular pressure and ganglion cell function in open angle glaucoma. BioRxiv Prepr 2020.01.30.924290.

Al-Nosairy KO, Thieme H \& Hoffmann MB (2020): Diagnostic performance of multifocal photopic negative response, pattern electroretinogram and optical coherence tomography in glaucoma. medRxiv 2020.03.18.20034785.

Anderson DR \& Patella VM (1999): Automated Static Perimetry. Mosby.

Bach M (n.d.). Bach - Freiburg Evoked Potentials.

Bach M, Brigell MG, Hawlina M, Holder GE, Johnson MA, McCulloch DL, Meigen T \& Viswanathan S (2013): ISCEV standard for clinical pattern electroretinography (PERG): 2012 update. Doc Ophthalmol 126: 1-7.

Bach M \& Hoffmann MB (2008): Update on the Pattern Electroretinogram in Glaucoma. Optom Vis Sci 85: 386.

Bach M \& Mathieu M (2004): Different effect of dioptric defocus vs. light scatter on the Pattern Electroretinogram (PERG). Doc Ophthalmol 108: 99-106.

Bahrami H (2006): Causal inference in primary open angle glaucoma: specific discussion on intraocular pressure. Ophthalmic Epidemiol 13: 283-289. 
medRxiv preprint doi: https://doi.org/10.1101/2020.07.05.20145714; this version posted July 7 , 2020. The copyright holder for this preprint (which was not certified by peer review) is the author/funder, who has granted medRxiv a license to display the preprint in perpetuity. It is made available under a CC-BY-NC-ND 4.0 International license.

Bode SFN, Jehle T \& Bach M (2011): Pattern Electroretinogram in Glaucoma Suspects: New Findings from a Longitudinal Study. Invest Ophthalmol Vis Sci 52: 4300-4306.

Bonomi L, Marchini G, Marraffa M, Bernardi P, Morbio R \& Varotto A (2000): Vascular risk factors for primary open angle glaucoma: the Egna-Neumarkt Study.

Ophthalmology 107: 1287-1293.

Campbell JP, Zhang M, Hwang TS, Bailey ST, Wilson DJ, Jia Y \& Huang D (2017):

Detailed Vascular Anatomy of the Human Retina by Projection-Resolved Optical Coherence Tomography Angiography. Sci Rep 7: 42201.

Chung JK, Hwang YH, Wi JM, Kim M \& Jung JJ (2017): Glaucoma Diagnostic Ability of the Optical Coherence Tomography Angiography Vessel Density Parameters. Curr Eye Res 42: 1458-1467.

Flammer J (1994): The vascular concept of glaucoma. Surv Ophthalmol, Ocular Blood Flow in the Progression and Therapy of Glaucoma 38: S3-S6.

Flammer J, Orgül S, Costa VP, Orzalesi N, Krieglstein GK, Serra LM, Renard J-P \& Stefánsson E (2002): The impact of ocular blood flow in glaucoma. Prog Retin Eye Res 21: 359-393.

Frangi AF, Niessen WJ, Vincken KL \& Viergever MA (1998): Multiscale vessel enhancement filtering. In: Wells WM, Colchester A \& Delp S (eds.) Med Image Comput Comput-Assist Interv — MICCAI'98, Lecture Notes in Computer Science. Berlin, Heidelberg: Springer 130-137.

Fritz CO, Morris PE \& Richler JJ (2012): Effect size estimates: current use, calculations, and interpretation. J Exp Psychol Gen 141: 2-18.

Gao SS, Jia Y, Zhang M, Su JP, Liu G, Hwang TS, Bailey ST \& Huang D (2016): Optical Coherence Tomography Angiography. Invest Ophthalmol Vis Sci 57: OCT27OCT36. 
medRxiv preprint doi: https://doi.org/10.1101/2020.07.05.20145714; this version posted July 7 , 2020. The copyright holder for this preprint (which was not certified by peer review) is the author/funder, who has granted medRxiv a license to display the preprint in perpetuity. It is made available under a CC-BY-NC-ND 4.0 International license.

Ghahari E, Bowd C, Zangwill LM, et al. (2019): Association of Macular and Circumpapillary Microvasculature with Visual Field Sensitivity in Advanced Glaucoma. Am J Ophthalmol 204: 51-61.

Halpern DL \& Grosskreutz CL (2002): Glaucomatous optic neuropathy: mechanisms of disease. Ophthalmol Clin N Am 15: 61-68.

Hanley JA \& McNeil BJ (1983): A method of comparing the areas under receiver operating characteristic curves derived from the same cases. Radiology 148: 839-843.

Holm S (1979): A Simple Sequentially Rejective Multiple Test Procedure. Scand J Stat 6: $65-70$.

Honda H, Anraku A, Ishida K, Enomoto N \& Tomita G (2019): Relationship between Macular Vessel Density and Focal Electroretinograms in Early Normal Tension Glaucoma. Curr Eye Res 44: 753-759.

Hood DC, Raza AS, de Moraes CGV, Liebmann JM \& Ritch R (2013): Glaucomatous damage of the macula. Prog Retin Eye Res 32: 1-21.

Hosari S, Hohberger B, Theelke L, Sari H, Lucio M \& Mardin CY (2020): OCT Angiography: Measurement of Retinal Macular Microvasculature with Spectralis II OCT Angiography - Reliability and Reproducibility. Ophthalmol J Int Ophtalmol Int J Ophthalmol Z Augenheilkd 243: 75-84.

Iwasaki M \& Inomata H (1986): Relation between superficial capillaries and foveal structures in the human retina. Invest Ophthalmol Vis Sci 27: 1698-1705.

Jia Y, Tan O, Tokayer J, et al. (2012): Split-spectrum amplitude-decorrelation angiography with optical coherence tomography. Opt Express 20: 4710-4725.

Kaneko M, Machida S, Hoshi Y \& Kurosaka D (2015): Alterations of Photopic Negative Response of Multifocal Electroretinogram in Patients with Glaucoma. Curr Eye Res 40: $77-86$. 
medRxiv preprint doi: https://doi.org/10.1101/2020.07.05.20145714; this version posted July 7 , 2020. The copyright holder for this preprint (which was not certified by peer review) is the author/funder, who has granted medRxiv a license to display the preprint in perpetuity. It is made available under a CC-BY-NC-ND 4.0 International license .

Kato F, Miura G, Shirato S, Sato E \& Yamamoto S (2015): Correlation between N2 amplitude of multifocal ERGs and retinal sensitivity and retinal nerve fiber layer thickness in glaucomatous eyes. Doc Ophthalmol Adv Ophthalmol 131: 197-206.

Kim SB, Lee EJ, Han JC \& Kee C (2017): Comparison of peripapillary vessel density between preperimetric and perimetric glaucoma evaluated by OCT-angiography. PloS One 12: e0184297.

Kim YK, Ha A, Na KI, Kim HJ, Jeoung JW \& Park KH (2017): Temporal Relation between Macular Ganglion Cell-Inner Plexiform Layer Loss and Peripapillary Retinal Nerve Fiber Layer Loss in Glaucoma. Ophthalmology 124: 1056-1064.

Kim YK, Jeoung JW \& Park KH (2017): Inferior Macular Damage in Glaucoma: Its Relationship to Retinal Nerve Fiber Layer Defect in Macular Vulnerability Zone. J Glaucoma 26: 126-132.

Kirkiewicz M, Lubiński W \& Penkala K (2016): Photopic negative response of full-field electroretinography in patients with different stages of glaucomatous optic neuropathy. Doc Ophthalmol 132: 57-65.

Koo TK \& Li MY (2016): A Guideline of Selecting and Reporting Intraclass Correlation Coefficients for Reliability Research. J Chiropr Med 15: 155-163.

Kurysheva NI, Maslova EV, Zolnikova IV, Fomin AV \& Lagutin MB (2018): A comparative study of structural, functional and circulatory parameters in glaucoma diagnostics. PloS One 13: e0201599.

Kwon YH, Fingert JH, Kuehn MH \& Alward WLM (2009): Primary Open-Angle Glaucoma. N Engl J Med 360: 1113-1124.

Lee EJ, Kim S, Hwang S, Han JC \& Kee C (2017): Microvascular Compromise Develops Following Nerve Fiber Layer Damage in Normal-Tension Glaucoma Without Choroidal Vasculature Involvement. J Glaucoma 26: 216-222. 
medRxiv preprint doi: https://doi.org/10.1101/2020.07.05.20145714; this version posted July 7 , 2020. The copyright holder for this preprint (which was not certified by peer review) is the author/funder, who has granted medRxiv a license to display the preprint in perpetuity. It is made available under a CC-BY-NC-ND 4.0 International license.

Liu L, Jia Y, Takusagawa HL, et al. (2015): Optical Coherence Tomography Angiography of the Peripapillary Retina in Glaucoma. JAMA Ophthalmol 133: 1045-1052.

Mansouri K (2016): Optical coherence tomography angiography and glaucoma: searching for the missing link. Expert Rev Med Devices 13: 879-880.

Masters BR (2004): Fractal Analysis of the Vascular Tree in the Human Retina. Annu Rev Biomed Eng 6: 427-452.

Mroczkowska S, Benavente-Perez A, Negi A, Sung V, Patel SR \& Gherghel D (2013): Primary Open-Angle Glaucoma vs Normal-Tension Glaucoma: The Vascular Perspective. JAMA Ophthalmol 131: 36-43.

Mwanza J-C, Durbin MK, Budenz DL, et al. (2012): Glaucoma diagnostic accuracy of ganglion cell-inner plexiform layer thickness: comparison with nerve fiber layer and optic nerve head. Ophthalmology 119: 1151-1158.

Oddone F, Lucenteforte E, Michelessi M, Rizzo S, Donati S, Parravano M \& Virgili G (2016): Macular versus Retinal Nerve Fiber Layer Parameters for Diagnosing Manifest Glaucoma: A Systematic Review of Diagnostic Accuracy Studies. Ophthalmology 123: 939-949.

Otsu N (1979): A Threshold Selection Method from Gray-Level Histograms. IEEE Trans Syst Man Cybern 9: 62-66. Presented at the IEEE Transactions on Systems, Man, and Cybernetics.

Pappelis K \& Jansonius NM (2019): Quantification and Repeatability of Vessel Density and Flux as Assessed by Optical Coherence Tomography Angiography. Transl Vis Sci Technol 8:.

Penteado RC, Zangwill LM, Daga FB, et al. (2018): Optical Coherence Tomography Angiography Macular Vascular Density Measurements and the Central 10-2 Visual Field in Glaucoma. J Glaucoma 27: 481-489. 
medRxiv preprint doi: https://doi.org/10.1101/2020.07.05.20145714; this version posted July 7 , 2020. The copyright holder for this preprint (which was not certified by peer review) is the author/funder, who has granted medRxiv a license to display the preprint in perpetuity. It is made available under a CC-BY-NC-ND 4.0 International license.

Preiser D, Lagrèze WA, Bach M \& Poloschek CM (2013): Photopic negative response versus pattern electroretinogram in early glaucoma. Invest Ophthalmol Vis Sci 54: 11821191.

R Core Team (2013) (n.d.). R: The R Project for Statistical Computing. R Lang Environ Stat Comput R Found Stat Comput Vienna Austria.

Rao HL, Pradhan ZS, Weinreb RN, et al. (2016): Regional Comparisons of Optical Coherence Tomography Angiography Vessel Density in Primary Open-Angle Glaucoma. Am J Ophthalmol 171: 75-83.

Reif R, Qin J, An L, Zhi Z, Dziennis S \& Wang R (2012): Quantifying Optical Microangiography Images Obtained from a Spectral Domain Optical Coherence Tomography System. Int J Biomed Imaging. Research Article Hindawi e509783.

Salowe R, Salinas J, Farbman NH, et al. (2015): Primary Open-Angle Glaucoma in Individuals of African Descent: A Review of Risk Factors. J Clin Exp Ophthalmol 6:. Scripsema NK, Garcia PM, Bavier RD, et al. (2016): Optical Coherence Tomography Angiography Analysis of Perfused Peripapillary Capillaries in Primary Open-Angle Glaucoma and Normal-Tension Glaucoma. Invest Ophthalmol Vis Sci 57: OCT611OCT620.

Shoji T, Zangwill LM, Akagi T, Saunders LJ, Yarmohammadi A, Manalastas PIC, Penteado RC \& Weinreb RN (2017): Progressive Macula Vessel Density Loss in Primary Open Angle Glaucoma: A Longitudinal Study. Am J Ophthalmol 182: 107-117.

Sutter EE (2001): Imaging visual function with the multifocal m-sequence technique. Vision Res 41: 1241-1255.

Tham Y-C, Li X, Wong TY, Quigley HA, Aung T \& Cheng C-Y (2014): Global prevalence of glaucoma and projections of glaucoma burden through 2040: a systematic review and meta-analysis. Ophthalmology 121: 2081-2090. 
medRxiv preprint doi: https://doi.org/10.1101/2020.07.05.20145714; this version posted July 7 , 2020. The copyright holder for this preprint (which was not certified by peer review) is the author/funder, who has granted medRxiv a license to display the preprint in perpetuity. It is made available under a CC-BY-NC-ND 4.0 International license.

Van Alstine AW \& Viswanathan S (2017): Test-retest reliability of the multifocal photopic negative response. Doc Ophthalmol 134: 25-36.

Van Melkebeke L, Barbosa-Breda J, Huygens M \& Stalmans I (2018): Optical Coherence Tomography Angiography in Glaucoma: A Review. Ophthalmic Res 60: 139-151.

Viswanathan S, Frishman LJ, Robson JG \& Walters JW (2001): The photopic negative response of the flash electroretinogram in primary open angle glaucoma. Invest Ophthalmol Vis Sci 42: 514-522.

Wilsey LJ \& Fortune B (2016): Electroretinography in glaucoma diagnosis. Curr Opin Ophthalmol 27: 118-124.

Yarmohammadi A, Zangwill LM, Diniz-Filho A, et al. (2016): Optical Coherence Tomography Angiography Vessel Density in Healthy, Glaucoma Suspect, and Glaucoma Eyes. Invest Ophthalmol Vis Sci 57: OCT451-OCT459.

Yarmohammadi A, Zangwill LM, Diniz-Filho A, et al. (2016): Relationship between Optical Coherence Tomography Angiography Vessel Density and Severity of Visual Field Loss in Glaucoma. Ophthalmology 123: 2498-2508.

Yarmohammadi A, Zangwill LM, Manalastas PIC, et al. (2018): Peripapillary and Macular Vessel Density in Patients with Primary Open-Angle Glaucoma and Unilateral Visual Field Loss. Ophthalmology 125: 578-587. 
medRxiv preprint doi: https://doi.org/10.1101/2020.07.05.20145714; this version posted July 7, 2020. The copyright holder for this preprint (which was not certified by peer review) is the author/funder, who has granted medRxiv a license to display the preprint in perpetuity.

\section{FIGURE LEGENDS}

Figure 1 (A) OCT angiography image of the parafovea analyzing superficial vascular plexus (SVP) of (i) a representative control's and (ii) a glaucoma participant's left eye. In (B) off-line post-processed images (see text for details) are depicted, where (B) the region of interest (ROI) is delineated and $(\mathrm{C})$ the $\mathrm{ROI}$ is used for subsequent analyses. (D) OCT-A of the peripapillary area extracting the superficial vascular complex of (i) a control and (ii) a glaucoma participant. In (E-F) off-line processed images are depicted, where $(E)$ is an image of the disc with delineation of ROI, (F) ROI of disc selected, (G) exclusion of big vessels from the analyzed area $(H)$. In (I) the ETDRS scans of the macula are depicted, with a visualization of the 1, 3,6 mm circles used for the analyses. In $(\mathrm{J})$ a macular OCT image is shown with the ganglion cell layer embraced between the lines. (K) Averaged $\mathrm{mfPhNR}$ trace with the $1^{\text {st }}$ negativity, i.e., a wave, the $1^{\text {st }}$ positivity, i.e., b wave, and the $2^{\text {nd }}$ negativity, i.e. the mfPhNR component. $(L)$ ssPERG to 0.8 checksize (upper panel) and $15^{\circ}$ checksize stimuli (lower panel) together with the frequency plot with the dominant response at the stimulation frequency, i.e., $15 \mathrm{~Hz}$, and the corresponding $\mathrm{P}$ values of each response. 
medRxiv preprint doi: https://doi.org/10.1101/2020.07.05.20145714; this version posted July 7 , 2020. The copyright holder for this preprint

Figure 2. Cross modal comparison of diagnostic performance. (A) Multifocal photopic negative response ratio (mfPhNR), (B) pattern electroretinogram (PERG) amplitude for $0.8^{\circ}$ checksize, $(\mathrm{C})$ peripapillary retinal nerve fiber layer thickness in micrometer, and (D) macular ganglion cell layer and inner plexiform layer thickness (mGCIPL). Vascular metrics of (E) parafoveal fractal dimension (pfFD) and (F) parafoveal vessel density (pfVD). Vascular metrics of $(G)$ peripapillary fractal dimension ( $p F D)$ and $(H)$ peripapillary vessel density (pVD). Independent t-tests were conducted except for parafoveal FD where Mann-Whitney test was performed (alpha-thresholds corrected for multiple comparisons are shown as subscripts). Panel title specifies the $y$-axis for each plot. 
medRxiv preprint doi: https://doi.org/10.1101/2020.07.05.20145714; this version posted July 7 , 2020. The copyright holder for this preprint

Figure 3. Area under curve (AUC) of receiver operating characteristics $(R O C)$ and AUC 95\% confidence intervals (Cl). (A) Electrophysiological parameters, multifocal photopic negative response ratio $(\mathrm{mfPhNR})$ and pattern electroretinogram $0.8^{\circ}$ amplitude (SSPERG). (B) Structural measures of peripapillary retinal nerve fiber layer thickness (pRNFL) and macular ganglion cell layer and inner plexiform layer thickness (mGCIPL). (C, D) vascular metrics of parafovea, which are (C) parafovea fractal density (pfFD) and vessel density (pfVD) vs peripapillary vascular metrics and (D) peripapillary fractal density ( $p F D)$ and peripapillary vessel density ( $p V D)$. $P$ values Significance levels are indicated where * indicates $P<0.05$, ${ }^{* *}$ indicates $P<0.01$ and *** indicates $\mathrm{P}<0.001$ where the null hypothesis is that true area $=0.5$. 
medRxiv preprint doi: https://doi.org/10.1101/2020.07.05.20145714; this version posted July 7 , 2020. The copyright holder for this preprint

Figure 4. (A) Correlation plots of multifocal photopic negative response ratio (mfPhNR) (upper panel) vs parafoveal fractal density (pfFD) and vessel density (pfVD) and macular ganglion cell layer and inner plexiform layer thickness (mGCIPL) and of mGCIPL (bottom) vs pfFD and pfVD measures. (B) Correlation plots of mfPhNR (top) vs peripapillary perfusion metrics and peripapillary retinal nerve fiber layer thickness (pRNFL) and of pRNFL (bottom) vs peripapillary fractal density ( $p F D)$ and vessel density $(\mathrm{pVD}) \cdot \mathrm{rs}^{2}=$ coefficient of determination. n.s= non- significant association. 
medRxiv preprint doi: https://doi.org/10.1101/2020.07.05.20145714; this version posted July 7, 2020. The copyright holder for this preprint (which was not certified by peer review) is the author/funder, who has granted medRxiv a license to display the preprint in perpetuity. It is made available under a CC-BY-NC-ND 4.0 International license .

Figure 1

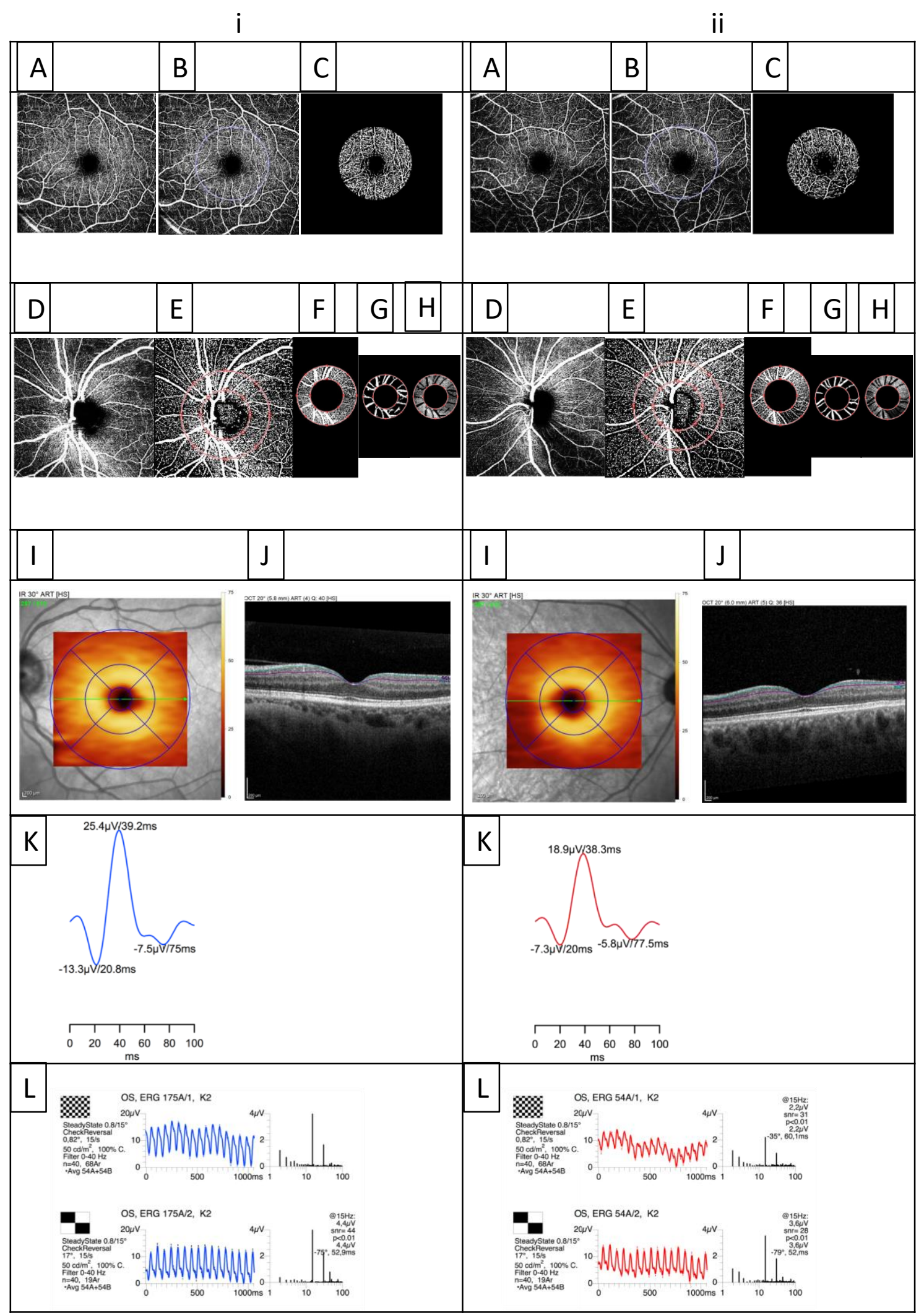


medRxiv preprint doi: https://doi.org/10.1101/2020.07.05.20145714; this version posted July 7, 2020. The copyright holder for this preprint (which was not certified by peer review) is the author/funder, who has granted medRxiv a license to display the preprint in perpetuity.

Figure 2
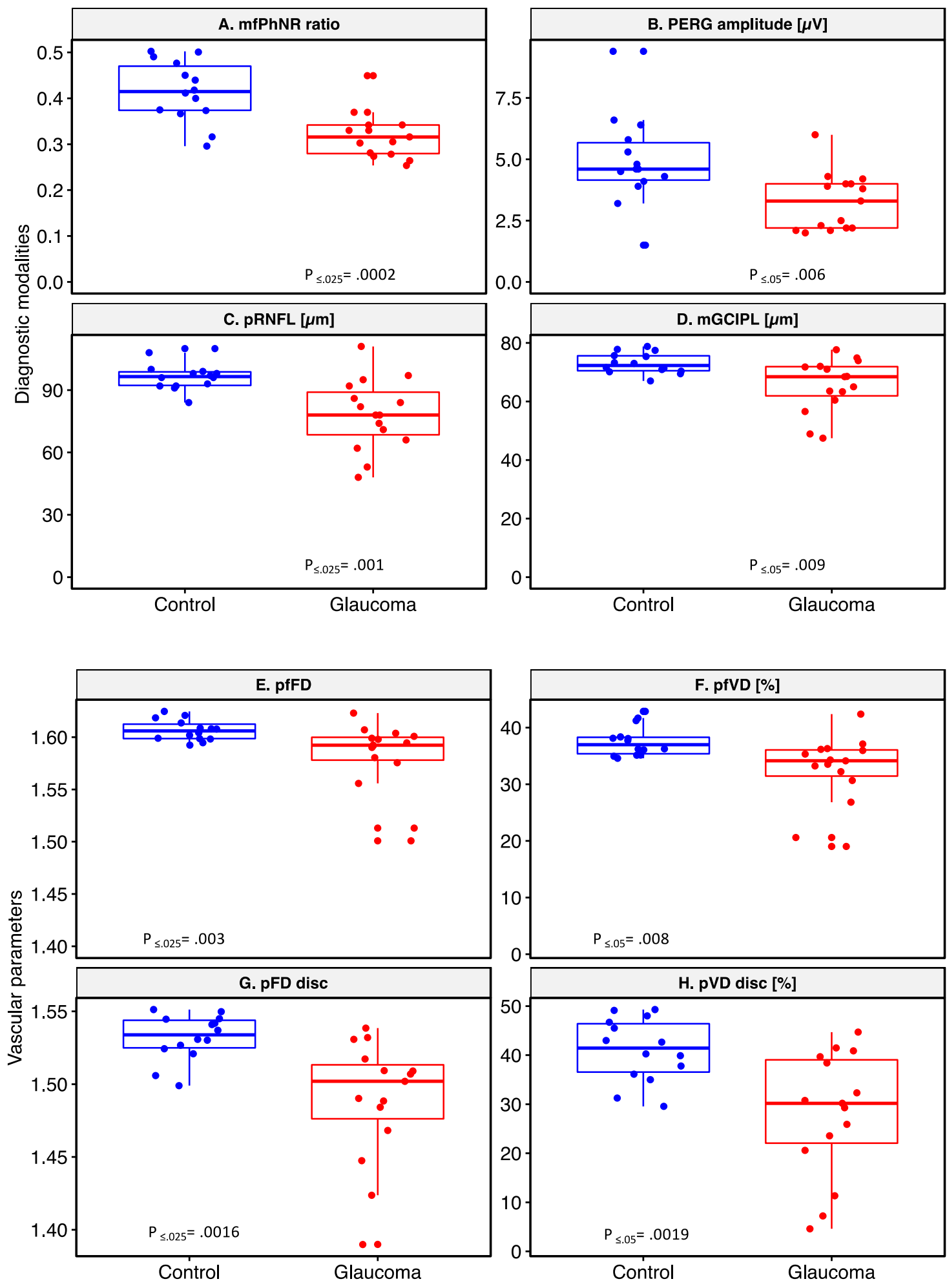
medRxiv preprint doi: https://doi.org/10.1101/2020.07.05.20145714; this version posted July 7, 2020. The copyright holder for this preprint (which was not certified by peer review) is the author/funder, who has granted medRxiv a license to display the preprint in perpetuity.

It is made available under a CC-BY-NC-ND 4.0 International license.

Figure 3
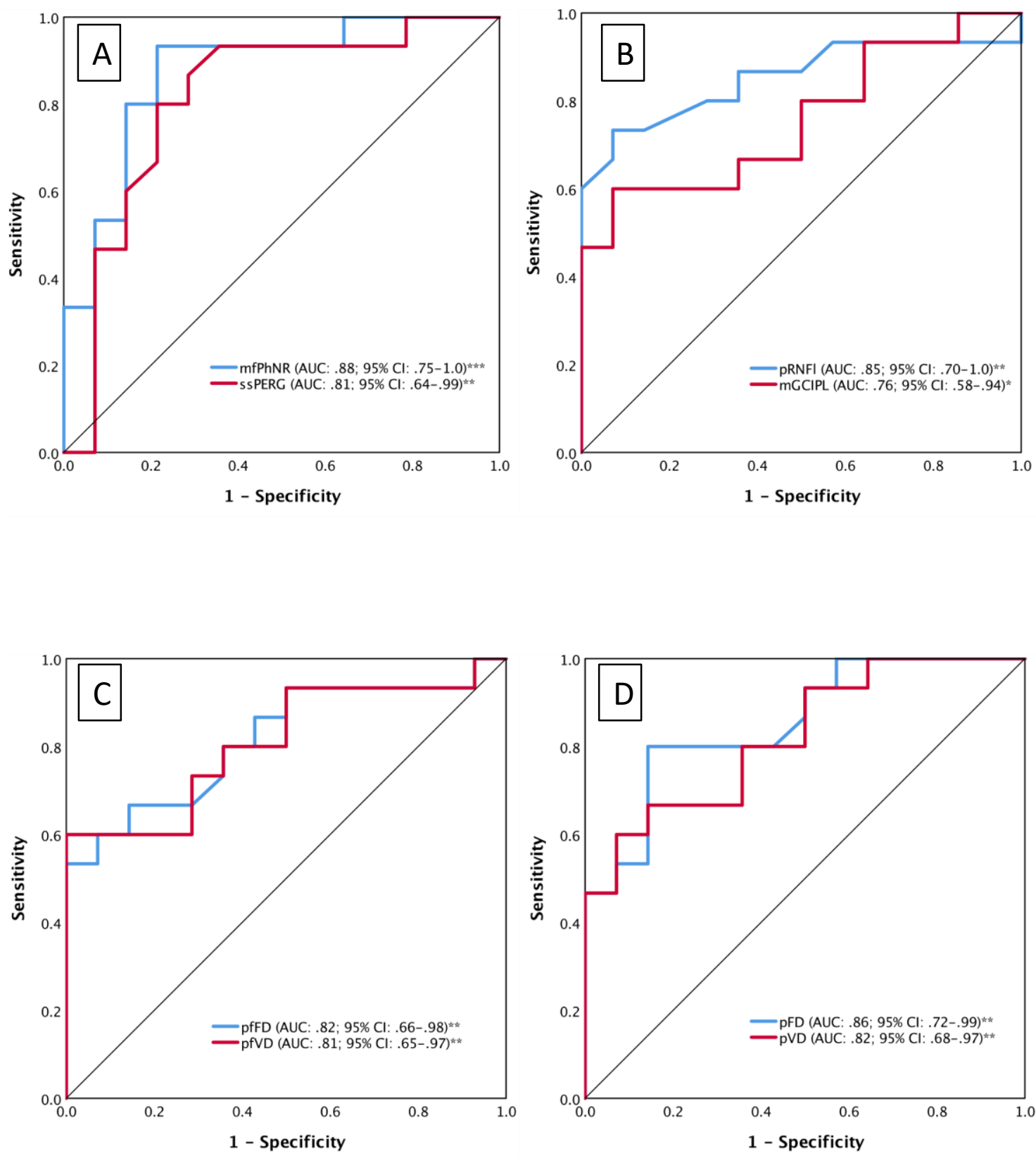
medRxiv preprint doi: https://doi.org/10.1101/2020.07.05.20145714; this version posted July 7, 2020. The copyright holder for this preprint (which was not certified by peer review) is the author/funder, who has granted medRxiv a license to display the preprint in perpetuity. It is made available under a CC-BY-NC-ND 4.0 International license.

Figure 4

A)
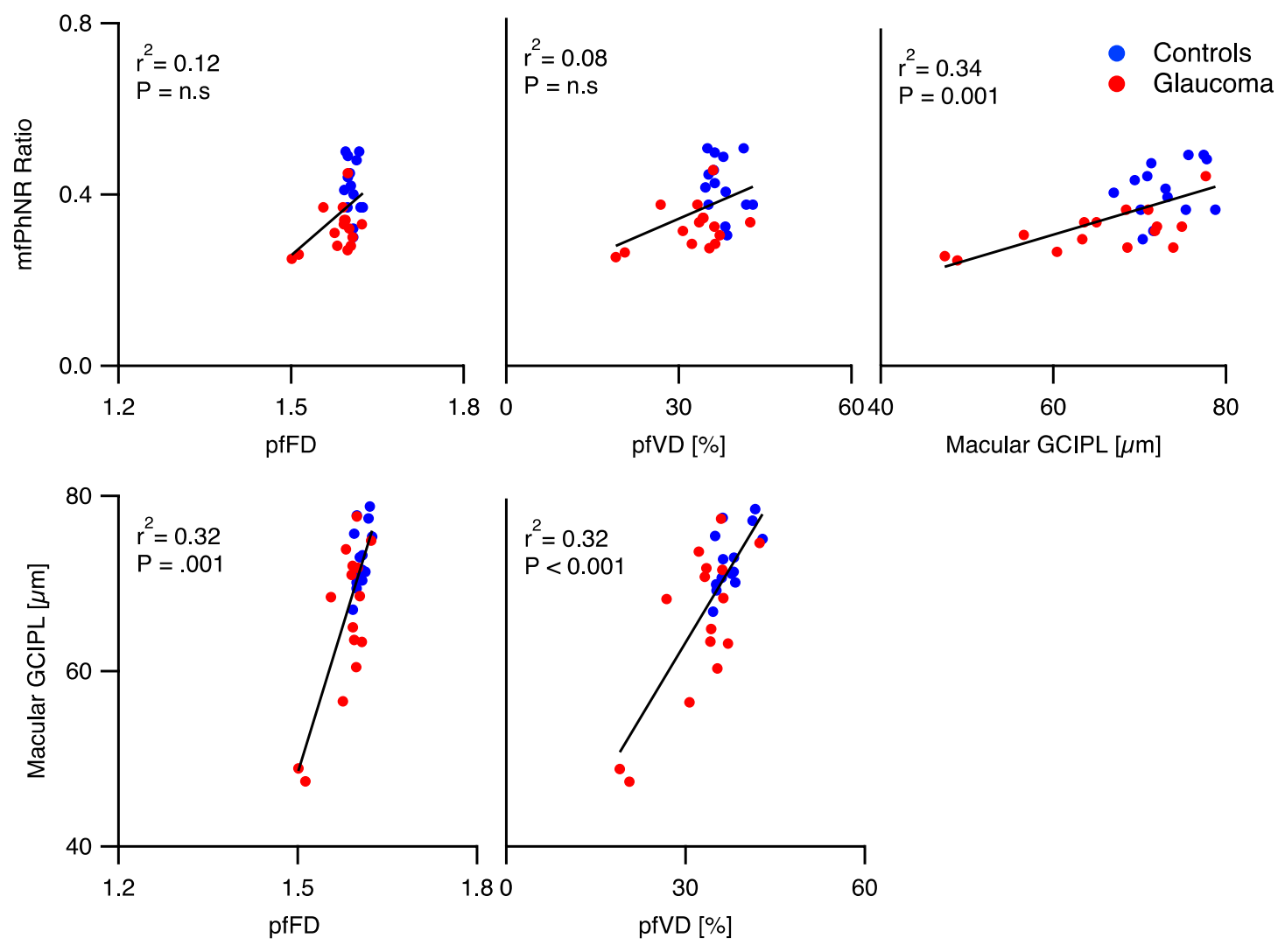

B)
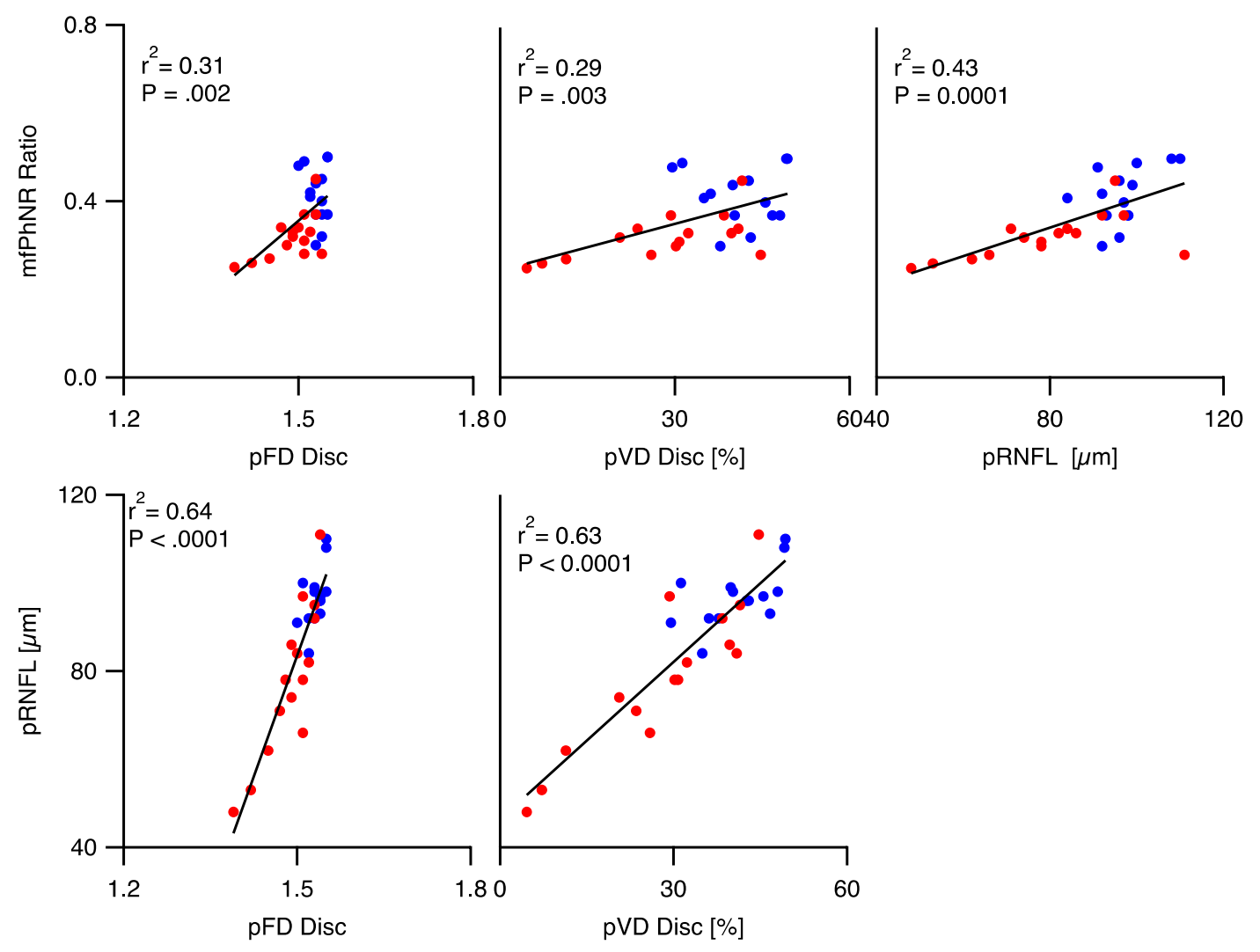
medRxiv preprint doi: https://doi.org/10.1101/2020.07.05.20145714; this version posted July 7 , 2020. The copyright holder for this preprint

(which was not certified by peer review) is the author/funder, who has granted medRxiv a license to display the preprint in perpetuity.

It is made available under a CC-BY-NC-ND 4.0 International license.

Table 1. Characteristics of normal and glaucoma participants

\section{Controls $(n=14) \quad$ Glaucoma $(n=15)$}

\begin{tabular}{|c|c|c|c|c|c|c|c|}
\hline & Mean & SEM & Mean & SEM & $d$ & $U$ & $P$ value \\
\hline Age [years] & 50.2 & 3.8 & 55.3 & 3.7 & 0.4 & 27 & $0.35^{i}$ \\
\hline $\begin{array}{l}\text { Visual field-MD } \\
\text { [dB] }\end{array}$ & $0.01^{\mathrm{iii}}$ & $\begin{array}{l}-0.5- \\
0.966^{\text {iii }}\end{array}$ & $-2.03^{\mathrm{iii}}$ & $\begin{array}{l}-5.03- \\
-0.97^{\mathrm{iii}}\end{array}$ & 2.3 & 85 & $<0.0001^{\mathrm{ii}}$ \\
\hline $\begin{array}{l}\text { Visual field-PSD } \\
\text { [dB] }\end{array}$ & $1.36^{\mathrm{iii}}$ & $\begin{array}{l}1.3- \\
1.5 \mathrm{iii}\end{array}$ & $2.02^{\mathrm{iii}}$ & $\begin{array}{l}1.6- \\
11.12^{\mathrm{iii}}\end{array}$ & 1.3 & 65 & $0.003^{\mathrm{ii}}$ \\
\hline pRNFL [ $[\mu \mathrm{m}]$ & 96.7 & 1.8 & 78.5 & 4.4 & 1.8 & 77 & $0.001^{i}$ \\
\hline pfGCIPL $[\mu \mathrm{m}]$ & 79.9 & 1.25 & 72.4 & 2.8 & 1.1 & 59 & $0.023^{i}$ \\
\hline mGCIPL $[\mu \mathrm{m}]$ & 73.0 & 0.9 & 65.6 & 2.3 & 1.4 & 68 & $0.009^{i}$ \\
\hline pf RNFL $[\mu \mathrm{m}]$ & 19.0 & .3 & 19.1 & 0.5 & 0.04 & 3 & $0.91^{i}$ \\
\hline mRNFL $[\mu \mathrm{m}]$ & 25.1 & .5 & 24.1 & .9 & 0.5 & 33 & $0.30^{i}$ \\
\hline \multicolumn{8}{|c|}{$\begin{array}{l}\mathrm{d}=\text { effect size with } \mathrm{U}[\%]=\text { probability percentage of non-overlap between the two distributions; } \\
\mathrm{SEM}=\text { standard error of mean; } \mathrm{MD}=\text { mean deviation; } \mathrm{PSD}=\text { pattern standard deviation; } \mathrm{pRNFL}= \\
\text { Averaged peripapillary retinal nerve fiber layer thickness; } \mathrm{m} / \mathrm{pfGCIPL}=\text { Averaged } \\
\text { macular/parafoveal thickness of ganglion cell layer and inner plexiform layer within } 6 / 3 \mathrm{~mm} \text { ETDRS } \\
\text { scans; } \mathrm{m} / \mathrm{pfRNFL=} \mathrm{Averaged} \mathrm{macular/parafoveal} \mathrm{retinal} \mathrm{nerve} \mathrm{fiber} \mathrm{layer} \mathrm{thickness} \mathrm{within} 6 / 3 \mathrm{~mm} \\
\text { ETDRS scans; } n=\text { number of eyes. } \\
\text { 'T-test } P \text { value and ii Mann-Whitney test } P \text { value.; not corrected for multiple testing due to } \\
\text { explorative nature. iii Median and interquartile range. }\end{array}$} \\
\hline
\end{tabular}


medRxiv preprint doi: https://doi.org/10.1101/2020.07.05.20145714; this version posted July 7 , 2020. The copyright holder for this preprint

(which was not certified by peer review) is the author/funder, who has granted medRxiv a license to display the preprint in perpetuity.

It is made available under a CC-BY-NC-ND 4.0 International license.

Table 2. Overview of electrophysiological parameters

\section{Controls $(n=14) \quad$ Glaucoma $(n=15)$}

\begin{tabular}{lllllllll} 
& & Mean & SEM & Mean & SEM & $d$ & U & P value $^{i}$ \\
\hline sSPERG & $0.8^{\circ}$ amplitude & 4.93 & 0.49 & 3.26 & 0.30 & 1.1 & 59 & 0.006 \\
& Ratio & 1.04 & 0.05 & 0.87 & 0.06 & 0.8 & 47 & 0.038 \\
mfPhNR & Averaged & 0.42 & 0.02 & 0.32 & 0.01 & 1.7 & 75 & 0.0002 \\
ratio & & & & & & & & \\
\hline
\end{tabular}

$\mathrm{d}=$ effect size with $\mathrm{U}[\%]=$ probability percentage of non-overlap between the two distributions; $\mathrm{SEM}=$ standard error of mean; SsPERG= steady state pattern electroretinogram; mfPhNR= multifocal photopic negative response; PERG amplitude is of $0.8^{\circ}$ checksize $[\mu \mathrm{V}] ; n=$ number of eyes.

¿ T-test $\mathrm{P}$ value; not corrected for multiple testing due to explorative nature. 
medRxiv preprint doi: https://doi.org/10.1101/2020.07.05.20145714; this version posted July 7 , 2020. The copyright holder for this preprint

(which was not certified by peer review) is the author/funder, who has granted medRxiv a license to display the preprint in perpetuity.

It is made available under a CC-BY-NC-ND 4.0 International license.

Table 3. Overview of vascular parameters

\begin{tabular}{|c|c|c|c|c|c|c|c|c|c|}
\hline & & & Contr & Is $(n=14)$ & Glauc & $\mathrm{ma}(\mathrm{n}=15)$ & & & \\
\hline & & & Mean & SEM & Mean & SEM & $d$ & $\mathrm{U}$ & $P$ value \\
\hline Parafovea & SVP & pfFD & $1.60^{i i i i}$ & $1.60-1.61^{i i i}$ & $1.59^{i i i}$ & $1.58-1.60^{i i i}$ & 1.3 & 65 & $0.003^{i i}$ \\
\hline & & pfVD & 37.60 & 0.72 & 32.52 & 1.59 & 1.1 & 59 & $0.008^{i}$ \\
\hline & ICP & pfFD & $1.58^{\mathrm{iii}}$ & $1.58-1.59^{i i i}$ & $1.57^{\mathrm{iii}}$ & $1.56-1.57^{\mathrm{iii}}$ & 1.4 & 68 & $0.001^{\mathrm{ii}}$ \\
\hline & & pfVD & 29.48 & 0.51 & 26.50 & 0.89 & 1.1 & 59 & $0.009^{i}$ \\
\hline & DCP & pfFD & 1.59 & 0.003 & 1.57 & 0.005 & 1.2 & 62 & $0.0034^{i}$ \\
\hline $\begin{array}{l}\text { Peripapillary } \\
\text { disc area }\end{array}$ & SVC & $\begin{array}{l}\text { pfVD } \\
\text { pFD } \\
\text { pVD }\end{array}$ & $\begin{array}{l}31.14 \\
1.53 \\
41.01\end{array}$ & $\begin{array}{l}0.68 \\
0.004 \\
1.73\end{array}$ & $\begin{array}{l}27.63 \\
1.49 \\
28.06\end{array}$ & $\begin{array}{l}0.83 \\
0.01 \\
3.27\end{array}$ & $\begin{array}{l}1.2 \\
1.7 \\
1.5\end{array}$ & $\begin{array}{l}62 \\
75 \\
71\end{array}$ & $\begin{array}{l}0.0033^{i} \\
0.0016^{i} \\
0.0019^{i}\end{array}$ \\
\hline $\begin{array}{l}\mathrm{d}=\text { effect size } \\
\text { SEM= standar } \\
\text { plexus; } D C P= \\
\text { parafoveal/pe } \\
\text { i T-test } P \text { valu } \\
\text { interquartile ra }\end{array}$ & ii $M$ & $\begin{array}{l}\text { ctal } \\
\text {-Wh }\end{array}$ & ensio & $\begin{array}{l}\mathrm{t} / \mathrm{pVD}=\mathrm{pa} \\
\text { value; not }\end{array}$ & $\begin{array}{l}\text { vea } \\
\text { ecte }\end{array}$ & $\begin{array}{l}\text { mplex; pf/r } \\
\text { ipapillary } \\
\text { r multiple t }\end{array}$ & $\begin{array}{l}\text { sel } \\
\text { sel } \\
\text { ing. }\end{array}$ & out & and \\
\hline
\end{tabular}


medRxiv preprint doi: https://doi.org/10.1101/2020.07.05.20145714; this version posted July 7 , 2020. The copyright holder for this preprint (which was not certified by peer review) is the author/funder, who has granted medRxiv a license to display the preprint in perpetuity.

It is made available under a CC-BY-NC-ND 4.0 International license .

\section{Table 4. Correlations between electrophysiological, structural and vascular parameters}

\begin{tabular}{|c|c|c|c|c|c|c|c|c|c|c|}
\hline & & \multicolumn{9}{|c|}{$r_{s}, P$ value, $\left[95 \% \text { confidence interval of } r_{s}\right]^{c}$} \\
\hline & & \multicolumn{3}{|c|}{ Functional } & \multicolumn{3}{|c|}{ Structural } & \multicolumn{3}{|c|}{ Vascular } \\
\hline & & mfPhNR & PERG & VF-MD & pRNFL & pfGCIPL & mGCIPL & pfFD & pfVD & pFD \\
\hline \multirow{2}{*}{ Functional } & PERG & $\begin{array}{l}0.60 \\
0.001 \\
{[0.34-0.78]}\end{array}$ & 1 & & & & & & & \\
\hline & VF-MD & $\begin{array}{l}0.76 \\
<0.0001 \\
{[0.53-0.89]}\end{array}$ & $\begin{array}{l}0.53 \\
0.003 \\
{[0.19-0.80]}\end{array}$ & 1 & & & & & & \\
\hline \multirow{3}{*}{ Structural } & pRNFL & $\begin{array}{l}0.66 \\
0.0001 \\
{[0.26-0.90]}\end{array}$ & $\begin{array}{l}0.53 \\
0.003 \\
{[0.20-0.78]}\end{array}$ & $\begin{array}{l}0.62 \\
0.0003 \\
{[0.27-0.87]}\end{array}$ & 1 & & & & & \\
\hline & pfGCIPL & $\begin{array}{l}0.58 \\
0.001 \\
{[0.29-0.77]}\end{array}$ & $\begin{array}{l}0.32 \\
0.09 \\
{[-.05-0.66]}\end{array}$ & $\begin{array}{l}0.48 \\
0.008 \\
{[0.07-0.79]}\end{array}$ & $\begin{array}{l}0.56 \\
0.002 \\
{[0.23-0.78]}\end{array}$ & 1 & & & & \\
\hline & mGCIPL & $\begin{array}{l}0.58 \\
0.001 \\
{[0.28-0.79]}\end{array}$ & $\begin{array}{l}0.41 \\
0.027 \\
{[0.06-0.70]}\end{array}$ & $\begin{array}{l}0.51 \\
0.005 \\
{[0.13-0.81]}\end{array}$ & $\begin{array}{l}0.73 \\
<0.0001 \\
{[0.49-0.86]}\end{array}$ & $\begin{array}{l}0.93 \\
0.0001 \\
{[0.84-0.97]}\end{array}$ & 1 & & & \\
\hline \multirow{4}{*}{ Vascular } & pfFD & $\begin{array}{l}.34 \\
.07 \\
{[.001-.62]}\end{array}$ & $\begin{array}{l}0.24 \\
0.20 \\
{[-.17-0.58]}\end{array}$ & $\begin{array}{l}0.52 \\
0.0004 \\
{[0.17-0.76]}\end{array}$ & $\begin{array}{l}0.30 \\
0.12 \\
{[-.11-0.64]}\end{array}$ & $\begin{array}{l}0.57 \\
0.001 \\
{[0.27-0.76]}\end{array}$ & $\begin{array}{l}0.57 \\
0.001 \\
{[0.25-0.78]}\end{array}$ & 1 & & \\
\hline & pfVD & $\begin{array}{l}0.29 \\
0.13 \\
{[-.05-0.58]}\end{array}$ & $\begin{array}{l}0.21 \\
0.27 \\
{[-.18-0.55]}\end{array}$ & $\begin{array}{l}0.52 \\
0.004 \\
{[0.20-0.74]}\end{array}$ & $\begin{array}{l}0.29 \\
0.12 \\
{[-.12-0.63]}\end{array}$ & $\begin{array}{l}0.56 \\
0.001 \\
{[0.25-0.76]}\end{array}$ & $\begin{array}{l}0.57 \\
0.001 \\
{[0.25-0.80]}\end{array}$ & $\begin{array}{l}0.99 \\
<0.0001 \\
{[0.98-1.0]}\end{array}$ & 1 & \\
\hline & pFD & $\begin{array}{l}0.56 \\
0.002 \\
{[.19-82]}\end{array}$ & $\begin{array}{l}0.52 \\
0.004 \\
{[0.19-0.75]}\end{array}$ & $\begin{array}{l}0.54 \\
0.002 \\
{[0.18-0.79]}\end{array}$ & $\begin{array}{l}0.80 \\
0.0001 \\
{[0.60-0.92]}\end{array}$ & $\begin{array}{l}0.49 \\
0.007 \\
{[0.12-0.76]}\end{array}$ & $\begin{array}{l}0.65 \\
0.0001 \\
{[0.33-0.86]}\end{array}$ & $\begin{array}{l}0.39 \\
0.037 \\
{[0.04-.067]}\end{array}$ & $\begin{array}{l}0.37 \\
0.046 \\
{[0.02-0.65]}\end{array}$ & 1 \\
\hline & pVD & $\begin{array}{l}0.54 \\
0.003 \\
{[0.14-.082]}\end{array}$ & $\begin{array}{l}0.49 \\
0.007 \\
{[0.19-0.74]}\end{array}$ & $\begin{array}{l}0.48 \\
0.008 \\
{[0.08-0.78]}\end{array}$ & $\begin{array}{l}0.79 \\
0.0001 \\
{[0.57-0.93]}\end{array}$ & $\begin{array}{l}0.45 \\
0.014 \\
{[0.06-0.73]}\end{array}$ & $\begin{array}{l}0.64 \\
0.0001 \\
{[0.34-0.84]}\end{array}$ & $\begin{array}{l}0.35 \\
0.07 \\
{[-.07-0.66]}\end{array}$ & $\begin{array}{l}0.34 \\
0.07 \\
{[-.07-0.65]}\end{array}$ & $\begin{array}{l}0.99 \\
<0.0001 \\
{[0.98-1.0]}\end{array}$ \\
\hline \multicolumn{11}{|c|}{ 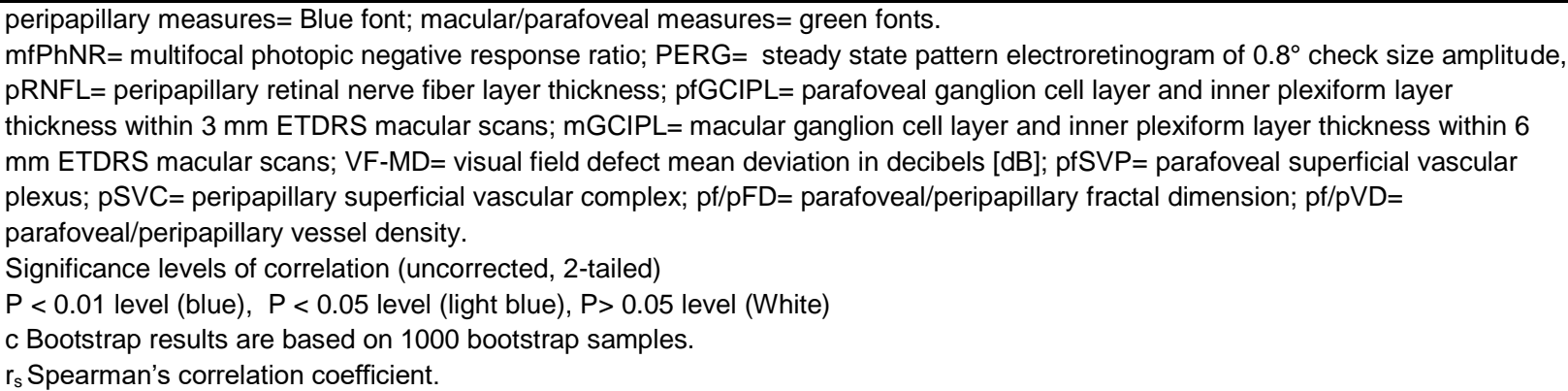 } \\
\hline
\end{tabular}

